DE

M E D I C I N A

T R O P I C A L

$\mathrm{DE}$

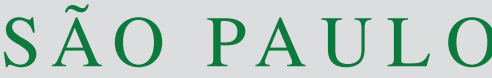

JOURNAL OF THE SÃO PAULO INSTITUTE OF TROPICAL MEDICINE

'Universidade de São Paulo, Faculdade de Medicina, Departamento de Moléstias Infecciosas e Parasitárias, São Paulo, São Paulo, Brazil

${ }^{2}$ Pontifícia Universidade Católica de Campinas, Faculdade de Medicina, Programa de Pós-Graduação em Ciências da Saúde, Campinas. São Paulo, Brazil

${ }^{3}$ Universidade de São Paulo, Instituto de Medicina Tropical de São Paulo, Laboratório de Bacteriologia (LIM-54), São Paulo, São Paulo, Brazil

${ }^{4}$ Universidade de São Paulo, Faculdade de Medicina, Disciplina de Hematologia, São Paulo, São Paulo, Brazil

Correspondence to: Silvia Figueiredo Costa

Universidade de São Paulo, Instituto de Medicina Tropical de São Paulo, Laboratório de Bacteriologia (LIM-54), Av. Dr. Enéas de Carvalho Aguiar, 470, Cerqueira Cesar, CEP 05403-000, São Paulo, SP, Brazil Tel: + 5511 3066-7030,

Fax: + $55113066-7029$

E-mail: costasilvia@ig.com.br, silviacosta@usp.br

Received: 30 August 2018

Accepted: 26 November 2018

\section{Bloodstream infection in hematopoietic stem cell transplantation outpatients: risk factors for hospitalization and death}

\author{
Rachel Russo', Elisa Teixeira Mendes ${ }^{(1,2}$, Anna Sara Levin ${ }^{1,3}$, Frederico \\ Dulley $^{4}$, Maura S. Oliveira', Maria Aparecida Shikanai-Yasuda', Silvia \\ Figueiredo Costa ${ }^{(1,3}$
}

\section{ABSTRACT}

We described 235 bloodstream infection (BSI) episodes in 146 hematopoietic stem cell transplantation (HSCT) outpatients and evaluated risk factors for hospitalization and death. Records of outpatients presenting with positive blood cultures over a 5-year period (January 2005 to December 2008) were reviewed. Variables with $\mathrm{p}<0.1$ in bivariate analysis were used in a regression logistic model. A total of 266 agents were identified, being $175(66.7 \%)$ gramnegative, $80(30.3 \%)$ gram-positive bacteria and $9(3.4 \%)$ fungi. The most common underlying disease was acute leukemia 40 (27.4\%), followed by lymphoma non-Hodgkin 26 (18\%) and 87 patients $(59.6 \%)$ were submitted to allogeneic hematopoietic stem cell transplant (HSCT). BSI episodes were more frequent during the first 100 days after transplantation (183 or $77.8 \%$ ), and ninety-one (38.7\%) episodes of BSI occurred up to the first 30 days. Hospitalization occurred in $26 \%$ of the episodes and death in $10 \%$ of cases. Only autologous HSCT was protector for hospitalization. Although, central venous catheter (CVC) withdrawal and the Multinational Association of Supportive Care in Cancer (MASCC) score up to 21 points were protector factors for death in the bivariate analysis, only MASCC remained as protector.

KEYWORDS: Bacteremia. Hematopoietic stem cell transplantation. Outpatients. Outcome. Resistance.

\section{INTRODUCTION}

Bloodstream infection (BSI) is the most relevant infections in patients undergoing hematopoietic stem cell transplant (HSCT) with high morbidity and mortality ${ }^{1}$. Until recently, gram-positive bacteria (GPB) were the most common agents causing BSI in these patients; moreover, in the last years there has been an increase of gramnegative bacteria (GNB) in several hospitals ${ }^{2}$.

Despite the increase in the number of allogeneic (allo) HSCT patients with early discharge and outpatient autologous (auto) transplantation programs; there is a lack of studies evaluating the safety of treating infections in HSCT outpatients.

The objective of this study was to evaluate the etiological agents causing BSI in HSCT outpatients as well as the risk factors associated with hospitalization and 30-day mortality.

\section{METHODS}

The Hospital das Clinicas is a teaching hospital with 2,200-beds and is a reference 
center for auto and allo- HSCT in Brazil. The outpatient unit is open from 7 am to $7 \mathrm{pm}$, every day of the week, including weekends. All patients submitted to HSCT were hospitalized at the time of transplantation.

Records of outpatients presenting with positive blood cultures over a 5-year period (January 2005 to December 2008) were reviewed. This study was approved by the Ethics Committee of the Hospital das Clinicas of University of Sao Paulo.

The BSI definition used were patients with positive blood culture collected through the central venous catheter (CVC) or a peripheral access during a period in which patients had fever and physicians had described antibiotics. The end points evaluated were hospitalization and 30-day mortality BSI onset. Clinical and demographic variables at the time of BSI, such as gender, age, underlying disease, length of hospitalization, type of HSCT, CVC (type and withdrawal), the presence of mucositis or graft-versushost disease (GVHD) and Multinational Association of Supportive Care in Cancer (MASCC) risk index score were evaluated. Hospitalizations depended on the clinical status, and when possible, the treatment was administered in the outpatient unit in which blood cultures were indicated in the presence of fever, hemodynamic instability or any infectious symptoms.

Microorganism identification and antimicrobial susceptibility test was performed using Vitek ${ }^{\circledast}$ (laboratory BioMérieux) and disk diffusion test followed the updated recommendations of CLSI (Clinical and Laboratory Standards Institute).

Data were analyzed using the softwares Epi Info version 3.5.1 and STATA. The two-tailed Fisher's exact test was used for categorical variables and the Wilcoxon test was used for continuous variables. Logistic regression models were developed to identify factors associated with hospitalization within 21 days onset of BSI and 30-day mortality onset BSI. All non-overlapping variables with $\mathrm{p}<0.1$ on bivariate analysis were entered into a stepwise forward model. A p-value $<0.05$ was considered statistically significant.

\section{RESULTS}

A total of 743 HSCT outpatients were evaluated during the study period and the records of 146 of them were analyzed. A total of 235 BSI episodes were identified among the 146 patients evaluated, being 207 (88\%) monomicrobial and $28(12 \%)$ polymicrobial. The hospitalization occurred in $61(26 \%)$ episodes, the more frequent reason was septic shock, 18/61 (31\%) (Table 1). A total of 266 agents were isolated, being 175 (66.7\%) gram-negative bacteria (GNB),
80 (30.3\%) gram-positive bacteria (GPB) and 9 (3.4\%) fungi (Table 1).

Resistance to cefepime in $P$. aeruginosa was identified in only $2 / 15(13 \%)$ of the isolated agents, to imipenem in $2 / 14(14 \%)$, and to meropenem in $3 / 10$ (27\%). Among Enterobacter cloacae, resistance to cefepime occurred in $3 / 11(27 \%)$ cases, no carbapenem resistance was identified. Among Acinetobacter spp, resistance to cefepime occurred in $3 / 24$ (14\%) and resistance to imipenem in $2 / 24(8 \%)$. Resistance to levofloxacin occurred in $1 / 39$ (3\%) and to trimethoprim-sulfamethoxazole in 3/39 (8\%) of $S$. maltophilia isolates. Resistance to vancomycin was identified in 7/9 (78\%) of E. faecium BSI. Gram-negative bacteria accounted for $72 \%$ of bloodstream infections in allogeneic transplants and $62 \%$ of autologous ones $(p=0.12)$. The mean time between transplantation and BSI was higher among allogeneic than autologous HSCT patients (145.5 and 44.1 days, respectively), probably because allogeneic patients remain hospitalized for longer periods after transplantation and at higher risk of infection after discharge. Death in 30 days were $8.5 \%$ in autologous and $15.2 \%$ in allogenic HSCT $(p=0.17)$. Median time between positive culture and death in days were 56 days in gram-negative and 27 days in gram-positive infections.

The bivariate analysis showed that previous use of levofloxacin, MASCC score higher than 21 and autologous (auto)-HSCT were protector factors and neutropenia was a risk factor for hospitalization. Moreover, only auto-HSCT remained as protector in the multivariate analysis (Table 2). The bivariate analysis showed that the CVC withdrawal, and MASCC higher than 21 points were protector factors for death (Table 2). Moreover, only MASCC score remained as protector (Table 2).

\section{DISCUSSION}

We observed a high proportion of GNB-BSI in our HSCT outpatient unit. The predominance of GNB has been reported by Brazilian studies that evaluated HSCT inpatients ${ }^{3}$. In our casuistic, BSI episodes occurred mainly in the first 100 days after the transplantation, similarly to other studies in the literature ${ }^{1,2}$ and $S$. maltophilia was the most frequent agent in both monomicrobial and polymicrobial BSI. In general, this agent causes outbreaks in BMT settings ${ }^{4}$. Moreover, as in our hospital, a recent study has shown that $S$. maltophilia and P. aeruginosa were the most commonly isolated GNB in HSCT patients ${ }^{5}$. We observed a high frequency of infection caused by waterborne bacteria (18\%). Infection by these agents is rare even in neutropenic patients ${ }^{6}$. However, our service recommends the protection of the CVC's lumen with a 
Table 1 - Clinical characteristic of 235 bloodstream infection episodes in 146 HSCT outpatients in Hospital das Clinicas, Brazil

\begin{tabular}{|c|c|}
\hline Characteristic & $\mathrm{N}(\%)$ \\
\hline Mucositis & $63(25)$ \\
\hline $\begin{array}{l}\text { Grade of mucositis (\%) } \\
\text { I } \\
\text { II } \\
\text { III } \\
\text { IV }\end{array}$ & $\begin{array}{c}25(48) \\
15(29) \\
10(19) \\
2(4)\end{array}$ \\
\hline $\begin{array}{l}\text { GVHD (\%) } \\
\text { Skin } \\
\text { Gut } \\
\text { Lung }\end{array}$ & $\begin{array}{c}58(70) \\
48(60) \\
5(6)\end{array}$ \\
\hline $\begin{array}{l}\text { Grade of GVHD (\%) } \\
\text { I } \\
\text { II } \\
\text { III } \\
\text { IV }\end{array}$ & $\begin{array}{l}12(44) \\
4(15) \\
8(30) \\
3(11)\end{array}$ \\
\hline Severe neutropenia $\left(<100\right.$ cells $\left./ \mathrm{mm}^{3}\right)(\%)$ & $63(28)$ \\
\hline $\begin{array}{l}\text { Neutropenia } \\
\text { ANC, median (range) (cells } / \mathrm{mm}^{3} \text { ) } \\
\text { Length of neutropenia, median (range) (days) }\end{array}$ & $\begin{array}{c}2,300 \\
(0-37,600) \\
6(1-30)\end{array}$ \\
\hline $\begin{array}{l}\text { Imune recovery after transplant (\%) } \\
\text { Until } 30 \text { days after BMT } \\
30 \text { days to } 100 \text { days after BMT } \\
\text { After } 30 \text { days of BMT }\end{array}$ & $\begin{array}{l}91(39) \\
92(39) \\
52(22)\end{array}$ \\
\hline $\begin{array}{l}\text { CVC (\%) } \\
\text { Non-tunneled } \\
\text { Tunneled } \\
\text { Totally implantable } \\
\text { Absence }\end{array}$ & $\begin{array}{c}2(1) \\
191(84) \\
9(4) \\
25(11)\end{array}$ \\
\hline CVC infection (\%) & $19(9)$ \\
\hline CVC withdrawal (\%) & $66(33)$ \\
\hline $\begin{array}{l}\text { Previous usage of antimicrobials (\%) } \\
\text { Until } 30 \text { days before collection (\%) } \\
\text { On time of collection (\%) } \\
\text { Cefepime } \\
\text { Levofloxacin } \\
\text { Meropenem } \\
\text { Teicoplanin }\end{array}$ & $\begin{array}{l}190(81) \\
187(80) \\
139(60) \\
113(58) \\
52(27) \\
105(54) \\
136(70)\end{array}$ \\
\hline $\begin{array}{l}\text { BSI agents (\%) } \\
\text { Most frequent Gram-positive bacteria } \\
\text { Staphylococcus coagulase negative } \\
\text { Enterococcus faecium }\end{array}$ & $\begin{array}{c}80(30) \\
31(12 \%) \\
9(3 \%)\end{array}$ \\
\hline
\end{tabular}

plastic dressing to prevent exposure to tap water, a potential source of waterborne agents but it was not possible to assess patients' compliance with this recommendation. Thus, inappropriate care of $\mathrm{CVC}$ at home during baths might explain this finding ${ }^{7}$.

In our study the 30-day mortality onset BSI was $10 \%$ and hospitalization occurred in $26 \%$ of patients. Moreover, the multivariate analysis showed that autologous HSCT was the only independent protector factor for hospitalization.

\begin{tabular}{|c|c|}
\hline Characteristic & $\mathrm{N}(\%)$ \\
\hline Micrococcus spp & $9(3 \%)$ \\
\hline Staphylococcus aureus & $7(3 \%)$ \\
\hline Streptococcus pneumoniae & $4(1 \%)$ \\
\hline Most frequent Gram-negative bacteria & $175(67)$ \\
\hline Stenotrophomonas maltophilia & $39(15 \%)$ \\
\hline Acinetobacter spp & $24(9 \%)$ \\
\hline Pseudomonas aeruginosa & $15(6 \%)$ \\
\hline Burkholderia cepacia & $13(5 \%)$ \\
\hline Klebsiella spp & $12(4 \%)$ \\
\hline Enterobacter cloacae & $11(4 \%)$ \\
\hline Serratia marcescens & $9(3 \%)$ \\
\hline Agrobacterium spp & $8(3 \%)$ \\
\hline Fungi & $9(3)$ \\
\hline Candida spp & $6(2 \%)$ \\
\hline \multicolumn{2}{|l|}{ Cultures (\%) } \\
\hline Monomicrobial & $207(88)$ \\
\hline Polymicrobial & $28(12)$ \\
\hline $\begin{array}{l}\text { Hospitalization up to } 21 \text { days after } \\
\text { culture (\%) }\end{array}$ & $61(26)$ \\
\hline \multicolumn{2}{|l|}{ Hospitalization reasons (\%) } \\
\hline infection complications & $8(14)$ \\
\hline Sepsis & $12(14)$ \\
\hline Sepsis shock & $18(31)$ \\
\hline Others & 20 \\
\hline New infection (\%) & $84(36)$ \\
\hline $\begin{array}{l}\text { Length of positive culture until } \\
\text { hospitalization, media (range) (days) }\end{array}$ & $3.3(0-21)$ \\
\hline MASCC, median (range) & $22(8-26)$ \\
\hline Death up to 30 days (\%) & $22(10)$ \\
\hline $\begin{array}{l}\text { Time between positive culture and death, } \\
\text { median (range) (days) }\end{array}$ & $42(0-995)$ \\
\hline
\end{tabular}

CVC: central venous catheter; MASCC: Multinational Association for Supportive Care in Cancer Risk Index, GVHD: Graft-Versus-Host Disease. Others BSI agents: Leuconostoc spp, Bacillus spp, Sphingomonas paucimobilis, Chryseobacterium spp, E.coli, Leuconostoc spp, Aeromonas spp. Other: myelodysplastic syndrome (25\%), Fanconi anemia (25\%), myelofibrosis (12.5\%), Ewing' sarcoma (6.25\%), Krabbe disease $(6.25 \%)$, germinal cells tumor (6.25\%), adrenoleukodystrophy (6.25\%), seminoma (6.25\%).

MASCC score and CVC withdrawal were protective factors for death in the bivariate analysis. In addition, only MASCC score higher than 21, remained as protector factor in the multivariate analysis. Unfortunately, in our study the catheter removal was not carried out as recommended in the literature because of the difficulty of venous access.

In the literature the presence of infection is a major cause of death in HSCT patients ${ }^{1}$. Ortega et al showed that $10 \%$ of HSCT inpatients with infection evolved to death ${ }^{6}$. 
Table 2 - Risk factors for hospitalization and death in 30 days among 235 episodes of BSI in HSCT outpatients patients.

\begin{tabular}{|c|c|c|c|c|c|c|}
\hline \multirow{2}{*}{ Variables } & \multicolumn{2}{|c|}{ Hospitalization N (\%) } & \multirow{2}{*}{$\begin{array}{c}\text { Bivariate } \\
\text { Analysis } \\
\mathrm{RR}(\mathrm{Cl} 95 \%)\end{array}$} & \multirow{2}{*}{ P-value } & \multirow{2}{*}{$\begin{array}{c}\text { Multivariate } \\
\text { analysis } \\
\text { OR }(\mathrm{Cl} 95 \%)\end{array}$} & \multirow{2}{*}{$\mathrm{p}$-value } \\
\hline & No & Yes & & & & \\
\hline Previous usage of levofloxacin (\%) & $44(85)$ & $8(16)$ & $0.82(0.70-0.97)$ & 0.030 & $0.56(0.23-1.40)$ & 0.22 \\
\hline Autologous BMT (\%) & $74(88)$ & $10(12)$ & $0.75(0.65-0.86)$ & 0.0001 & $0.23(0.11-0.68)$ & 0.005 \\
\hline Bacteremia due to gram-positive* (\%) & $46(66)$ & $24(34)$ & $1.17(0.97-1.41)$ & 0.050 & $1.16(0.51-2.65)$ & 0.71 \\
\hline Mucositis (\%) & $43(68)$ & $20(32)$ & $1.11(0.91-1.33)$ & 0.16 & & \\
\hline Severe neutropenia (\%) & $38(60)$ & $25(40)$ & $1.28(1.02-1.60)$ & 0.007 & $1.67(0.71-3.92)$ & 0.24 \\
\hline CVC withdrawn (\%) & $52(79)$ & $14(21)$ & $0.91(0.77-1.07)$ & 0.19 & & \\
\hline $\begin{array}{l}\text { Length of BMT until bacteremia, median } \\
\text { (range) (days) }\end{array}$ & 174 & 61 & $60(6-746)$ & 0.21 & & \\
\hline ANC. median (range) cels $/ \mathrm{mm}^{3}$ & 164 & 61 & $220(0-23,400)$ & 0.12 & & \\
\hline MASCC. median & 174 & 59 & $18(8-26)$ & $<0.0001$ & & \\
\hline \multirow[t]{3}{*}{ MASCC score higher than $21(\%)$} & $101(82)$ & $23(18)$ & $0.82(0.70-0.96)$ & 0.008 & $0.55(0.27-1.13)$ & 0.10 \\
\hline & \multicolumn{2}{|c|}{ Death N (\%) } & \multirow{2}{*}{$\begin{array}{c}\text { Bivariate } \\
\text { Analysis } \\
\mathrm{RR}(\mathrm{Cl} \text { 95\%) }\end{array}$} & \multirow{2}{*}{ P-value } & \multirow{2}{*}{$\begin{array}{l}\text { Multivariate } \\
\text { analysis } \\
\text { OR (Cl 95\%) }\end{array}$} & \multirow{2}{*}{$\mathrm{p}$-value } \\
\hline & Yes & No & & & & \\
\hline Age. (median) & 32 & 38 & & 0.29 & & \\
\hline Previous usage of levofloxacin (\%) & $26(93)$ & $2(7)$ & $0.89(0.77-1.03)$ & 0.17 & & \\
\hline Autologous BMT (\%) & $54(92)$ & $5(8)$ & $0.93(0.86-1.01)$ & 0.17 & $3.73(0.90-15.28)$ & 0.06 \\
\hline Bacteremia Gram- positive* (\%) & $39(81)$ & $9(19)$ & $1.11(0.95-1.29)$ & 0.10 & & \\
\hline Bacteremia Gram-negative (\%) & $81(90)$ & $19(9)$ & $0.91(0.79-1.0)$ & 0.15 & & \\
\hline Fungi & $4(100)$ & 0 & $0.87(0.81-0.92)$ & 0.58 & & \\
\hline Mucositis (\%) & $38(83)$ & $8(17)$ & $1.02(0.92-1.12)$ & 0.41 & & \\
\hline GVHD (\%) & $34(83)$ & $7(17)$ & $1.07(0.92-1.25)$ & 0.21 & & \\
\hline Severe neutropenia (\%) & $32(82)$ & $7(18)$ & $1.06(0.90-1.23)$ & 0.28 & . & \\
\hline CVC withdrawal (\%) & $34(97)$ & $1(3)$ & $0.87(0.79-0.97)$ & 0.050 & $40(0.07-2.38)$ & 0.32 \\
\hline ANC, median (range) (cels $/ \mathrm{mm}^{3}$ ) & 2,350 & 1,250 & & 0.54 & & \\
\hline Duration of neutropenia. (days, mean) & 3.4 & 4.5 & & & & 0.43 \\
\hline MASCC. median & 21 & 16 & & 0.0001 & $0.78(0.68-0.90)$ & 0.001 \\
\hline MASCC score higher than $21(\%)$ ** & $127(88)$ & $18(12)$ & $0.90(0.83-1.02)$ & 0.07 & & \\
\hline Shock & $11(27)$ & $29(73)$ & $1.70(0.43-6.69)$ & 0.34 & & \\
\hline
\end{tabular}

CVC: central venous catheter; MASCC: Multinational Association for Supportive Care in Cancer Risk Index. GVHD: Graft-VersusHost Disease

Therefore, the proportion of deaths in the present study in outpatients was similar to that described in BSI HSCT inpatients ${ }^{8}$. Vancomycin-resistant enterococcus (VRE) mortality in HSCT patients ranges from $7 \%$ to $34 \%^{9}$ similar to our findings. In contrast, authors have reported a high mortality of BSI caused by carbapenem-resistant GNB in HSCT $^{10}$.

In conclusion, GNB were the most frequent agents causing BSI in HSCT outpatients in our hospital; hospitalization rate was low and auto-HSCT was a protector factor for hospitalization and the MASCC score higher than 21 points for 30-day mortality.

\section{FUNDING}

No funding of any kind has been received.

\section{CONFLICT OF INTERESTS}

None to declare. 


\section{REFERENCES}

1. Schuster MG, Cleveland AA, Dubberke ER, Kauffman CA, Avery RK, Husain S, et al. Infections in hematopoietic cell transplant recipients: results From the Organ Transplant Infection Project, a multicenter, prospective, cohort study. Open Forum Infect Dis. 2017;4:ofx050.

2. Averbuch D, Tridello G, Hoek J, Mikulska M, Akan H, Yanez San Segundo L, et al. Antimicrobial resistance in Gram-negative rods causing bacteremia in hematopoietic stem cell transplant patients: intercontinental prospective study of Infectious Diseases Working Party of the European Bone Marrow Transplantation group. Clin Infect Dis. 2017;65:1819-28.

3. Mendes ET, Dulley F, Basso M, Batista MV, Coracin F, Guimarães $\mathrm{T}$, et al. Healthcare-associated infection in hematopoietic stem cell transplantation patients: risk factors and impact on outcome. Int J Infect Dis. 2012;16:e424-8.

4. Labarca JA, Leber AL, Kern VL, Territo MC, Brankovic LE, Bruckner DA, et al. Outbreak of Stenotrophomonas maltophilia bacteremia in allogenic bone marrow transplant patients: role of severe neutropenia and mucositis. Clin Infect Dis. 2000;30:195-7.

5. Girmenia C, Bertaina A, Piciocchi A, Perruccio K, Algarotti A, Busca A, et al. Incidence, risk factors and outcome of preengraftment gram-negative bacteremia after allogeneic and autologous hematopoietic stem cell transplantation: an Italian prospective multicenter survey. Clin Infect Dis. 2017;65:188496.
6. Ortega M, Rovira M, Almela M, Marco F, de la Bellacasa JP, Martínez JA, et al. Bacterial and fungal bloodstream isolates from 796 hematopoietic stem cell transplant recipients between 1991 and 2000. Ann Hematol. 2005;84:40-6.

7. Toscano CM, Bell M, Zukerman C, Shelton W, Novicki TJ, Nichols WG, et al. Gram-negative bloodstream infections in hematopoietic stem cell transplant patients: the roles of needleless device use, bathing practices, and catheter care. Am J Infect Control. 2009;37:327-34.

8. McDiarmid S, Hutton B, Atkins H, Bence-Bruckler I, Bredeson C, Sabri E, et al. Performing allogeneic and autologous hematopoietic SCT in the outpatient setting: effects on infectious complications and early transplant outcomes. Bone Marrow Transplant. 2010;45:1220-6.

9. Tavadze M, Rybicki L, Mossad S, Avery R, Yurch M, Pohlman $\mathrm{B}$, et al. Risk factors for vancomycin-resistant enterococcus bacteremia and its influence on survival after allogeneic hematopoietic cell transplantation. Bone Marrow Transplant. 2014;10:1310-6.

10. Forcina A, Baldan R, Marasco V, Cichero P, Bondanza A, Noviello $\mathrm{M}$, et al. Control of infectious mortality due to carbapenemaseproducing Klebsiella pneumoniae in hematopoietic stem cell transplantation. Bone Marrow Transplant. 2017;52:114-9. 